\title{
Response of Sugar Beet Yield and Water Use Efficiency to Deficit Irrigation and Weed Competition under Drip Irrigation System \\ Abou-Zied, Kh. A. ${ }^{1}$; A. E. A. Abd El-All ${ }^{2}$ and A. M. Osman ${ }^{2}$ \\ ${ }^{1}$ Weed Research Central Laboratory, Agricultural Research Center, Giza, Egypt. \\ ${ }^{2}$ Soil \& Water and Environment Research Institute, Agricultural Research Center, Giza, Egypt.
}

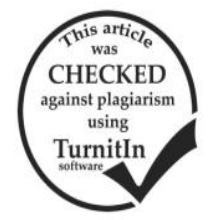

\section{ABSTRACT}

Under drip irrigation condition, two field experiments of sugar beet (Beta vulgaris L.) were conducted, in sandy soil, at ElBostan area, Aly Mubarak Experimental Farm, Southern El-Tahrir Region, El-Buhira Governorate, Egypt, during 2013/14 and 2014/15 winter seasons, to evaluate the impact of water deficit irrigation and its relation with the critical period of weeds infestation on sugar beet yield, quality and water use efficiency. The experimental design was a split-plot design, where three water irrigation regimes treatments, i.e. 60,80 and $100 \%$ of evapotranspiration $\left(\mathrm{ET}_{0}\right)$, were allocated in the main plots, and the ten weed removal intervals were allocated in the sub-plots which included five weed free for 3, 6, 9, 12 weeks after planting (WAP) and weed free the whole season, and five weed infestation for 3, 6, 9, 12 (WAP) and weed infestation for the whole season. The main findings indicated that the highest significant reduction on the fresh weights of grassy, broad-leaved and total weeds was obtained by irrigation at $60 \% \mathrm{ET}_{0}$ by14.8, 16.0 and $15.6 \%$, respectively, in 2013/14 season and 25.0, 13.6 and $17.3 \%$, respectively, in $2014 / 15$ season, as compared to $100 \% \mathrm{ET}_{0}$, which reflected in increases on root and gross sugar yield per faddan by 58.8 and $60.2 \%$, respectively, in 2013/14 season and 65.5 and $40.1 \%$, respectively, in 2014/15 season, as compared to irrigation at $100 \% \mathrm{ET}_{0}$. Furthermore, water use efficiency of irrigation at $60 \% \mathrm{ET}_{0}$ gave the highest values of root and sugar yield by $7.2 \mathrm{and} 1.2 \mathrm{~kg} / \mathrm{m}^{3}$, respectively, in the first season and 7.1 and $1.3 \mathrm{~kg} / \mathrm{m}^{3}$, respectively, in second season. The dominant annual weeds were the broadleaf weeds with infestation rates $3.0 \mathrm{~kg}$ and $3.5 \mathrm{~kg}$ fresh weight $/ \mathrm{m}^{2}$ in the first and second seasons, respectively. Whilst, the infestation rate of the grassy weeds was $1.3 \mathrm{~kg}$ and $1.4 \mathrm{~kg}$ fresh weight $/ \mathrm{m}^{2}$ in the both seasons, respectively. In the both seasons, the highest reduction on the fresh weight of the two weeds categories and their total was obtained from all weed free and weed infestation treatments $(>90 \%)$ as compared to weed infestation for the whole season, except with weed free for 3 weeks $(<70 \%)$. These results reflected on sugar beet yields (ton/fed). In the first season, the significant increasing on dry weight of tops, roots and the gross sugar yield (ton/fed) was between 118.6, 302.5 and $353.8 \%$, respectively, in weed free for the whole season to $58.5 \%$ for tops by weed free for 3 weeks, $135.2 \%$ for roots by weed free for 6 weeks and $50.0 \%$ for gross sugar yield by weed infestation for 9 weeks, as compared to weed infestation for the whole season. In second season, the significant increasing on dry weight of the tops, roots and gross sugar yield (ton/fed) was between $98.8,311.3$ and $288.7 \%$, respectively, in weed free for the whole season to $37.5 \%$ for the tops and $35.0 \%$ for the roots in weed free for 3 weeks and $106.5 \%$ in weed infestation for 6 weeks, as compared to weed infestation for the whole season. While, the rest weed free and weed infestation treatments in the both seasons didn't reach to significant increasing values. For sugar beet quality i.e. TSS, sucrose and purity $\%$, all weed free and weed infestation treatments gave the same values approximately in deferent intervals. Also, different weed removal intervals can raise water efficiency by $240-320 \%$ compared to leave the weeds to compete sugar beet plants for whole season. Concerning the interaction effects, the data indicated that the great reduction on the fresh weight of the two weed categories and their total was obtained from irrigation at $60 \% \mathrm{ET}_{0}$ with weed free for whole season, weed competition for $3 \mathrm{WAP}$ and weed free for $12 \mathrm{WAP}$, in both seasons. Also, the interactions between both 60 and $80 \% \mathrm{ET}_{0}$ irrigation regimes with both weed free for 12 weeks and the whole season gave the highest increasing on the roots and gross sugar yields (ton/fed) in the both seasons. The findings also revealed that the critical period of weed interference between 3 and 12 weeks after planting and the yield losses in this period. Thus, we can conclude that to save water irrigation and maximize root and sugar yields of sugar beet (ton/fed) must be irrigate at $60 \% \mathrm{ET}_{0}$ with controlling weeds until 12 week from planting.

Keywords: Sugar beet (Beta vulgaris L.) critical period, weed competition, deficit irrigation, water use efficiency.

\section{INTRODUCTION}

Sugar beet (Beta vulgaris L.) is one of an important sugar crop in the world and come in second rant crop after sugarcane for sugar production in Egypt. Vertical and horizontal expansion of sugar beet is one of the governmental plans in order to the gradually close the gap between sugar consumption and production. In Egypt, the area of sugar beet was 523188 faddans in 2016/17, 147631 faddans on reclaimed lands (Annual report, 2018). Cultivation sugar beet crop in the pilot farms at the newly reclaimed desert lands at west Nubaria and El-Bustan regions was successful, but the studies which conducted on the competition of weeds for sugar beet crop and linked it to the amount of irrigation water were very rare. Because the over population in Egypt, water become scare to the agricultural sector is becoming a major constraint for agricultural production. One way to maximize the use of this limited resource is through the use of a proper and efficient irrigation system. Area in a need to raise water use efficiency by new irrigation methods as drip irrigation water and it is considered as a highly efficient method of delivering water and fertilizer uniformly to most crops. Bucks and Davis (1986) demonstrated that drip irrigation increased the beneficial use of water, enhanced plant growth and yield, limited weed growth, decreased energy required and improved cultural practices. Badr (1987) found that the total applied irrigation water for sugar beet in the sandy soils of Nubaria region was $3364 \mathrm{~m}^{3} /$ fed under sprinkler irrigation and the water application efficiency value was $81.2 \%$. Awad et al. (2003) found that average seasonal applied irrigation water by sprinkler system was $2982 \mathrm{~m}^{3} / \mathrm{fed}$, while it was $3958 \mathrm{~m}^{3} /$ fed for surface irrigation, and they reported that root yields were 25.81 and $20.94 \mathrm{t} /$ fed for sprinkler and surface irrigation, respectively. On the other hand, weed competition is one of the major obstacles in preventing the achievement of maximum sugar beet yield especially under drip irrigation condition due to the increase in number of irrigation. Weeds and sugar beet plants were compete for the necessary elements of growth such as light, water and nutrients, in addition there are harbor insects and increase the incidence of diseases and harvest losses. The critical period of weedsugar beet competition and amount of sugar beet yield losses due to weed competition differed by differing the time appeared of these weeds after sugar beet emergence (Kropff et al., 1992). Deveikyte and Seibutis (2006) reported that the sugar beet plants are a poor competitor with weeds. Also, 
uncontrolled weeds which emerge with the crop typically could cause yield losses by 50 to $100 \%$. Salehi et al. (2006) showed that sugar beet root yield was decreased by $92.9 \%$ and $61.2 \%$ presence of weeds during 1999 and 2000 growing seasons, respectively. Alaoui et al. (2003) indicated that sugar beet sucrose yield was reduced by 99 to $100 \%$ by full-season weed interference and by 5 or $10 \%$ if weeds were allowed to interfere with sugar beet for 2 to 2.5 or 5 to 5.5 weeks after sugar beet emergence. The critical timing of weed removal to avoid 5 and $10 \%$ root yield loss was 30 and 43 days after sugar beet emergence, respectively (Odero et al., 2009). It is possible to reduce the loss of irrigation water and increase the efficiency of water consumption by adopting a good irrigation system and reduce the loss of water resulting from the presence of weeds by removing weeds at the time of weed competition for sugar beet. These present investigation was carried out to determine the response of sugar beet yield and juice quality to deficit irrigation and estimation the critical period of weed competition and water use efficiency of sugar beet plants.

\section{MATERIALS AND METHODS}

Two field experiments were carried out in El-Bostan area - Aly Mubarak Experimental Farm, Southern El-Tahrir Region, (30.57 $\mathrm{N}$ latitude and $30.71^{\circ} \mathrm{E}$ longitude), ElBuhira Governorate, Egypt, during 2013/14 and 2014/15 successive winter seasons, to determinate the impact of deficit water irrigation and critical period of weeds infestation on sugar beet yield and its quality and water use efficiency under drip irrigation system and sandy soil conditions. The experimental design was split-plot with four replications.

\section{Studied factors:}

- Factor A: In main plots, three irrigation regime treatments into the whole plots as follows:

1) $60 \%$ of Evapotranspiration $\left(\mathrm{ET}_{0}\right)$.

2)2) $80 \%$ of $\mathrm{ET}_{0}$. 3) $100 \%$ of $\mathrm{ET}_{0}$.
- Factor B: In sub-plots, ten duration of weed free and weed infestation periods into sub-division of the whole plots as follows:

1) Weed free for 3 weeks after planting (WAP).

2) Weed free for 6 WAP.

3) Weed free for 9 WAP.

4) Weed free for 12 WAP.

5) Weed free for the whole season.

6) Weed infestation for 3 WAP.

7) Weed infestation for 6 WAP.

8) Weed infestation for 9 WAP.

9) Weed infestation for 12 WAP.

10) Weed infestation for the whole season.

In 1 to 5 treatments, the crop is kept free the weeds until a certain time, after which weeds are allowed to grow and in 6 to 10 treatments, weeds are allowed to grow from the beginning to a certain time, after which they are removed until the end of the growth cycle.

Weed removal were done by hand pulling and hand hoeing at the estimated periods.

The sugar beet variety viz. Gloria (polygerm) was planted, at $3 \mathrm{~kg} / \mathrm{fed}$, on $16^{\text {th }}$ and $9^{\text {th }}$ of October, in the first and second seasons, and harvested in $25^{\text {th }}$ and $18^{\text {th }}$ of April, respectively. Plot area was $10.5 \mathrm{~m}^{2}$, number of ridges was 5 with length of $3.5 \mathrm{~m}$. and $0.6 \mathrm{~cm}$ in width. The optimum agronomics practices recommended for the region were done.

Soil samples were collected before cultivation to determine the physical and chemical characteristics of the experimental site (Table 1).

The irrigation network consisted of a main delivery pipe (PE, $32 \mathrm{~mm}$ ) and the secondary ones (PE, $25 \mathrm{~mm})$. The drip laterals were of $16 \mathrm{~mm}$ diameter polyethylene with wide space $0.6 \mathrm{~m}$ and the space between emitters was $0.25 \mathrm{~m}$. The discharge rate of the emitter was 4 liters/hour.

Table 1. Means of soil physical and chemical characteristics of the experimental site.

\begin{tabular}{|c|c|c|c|c|c|c|c|c|c|c|}
\hline \multirow{2}{*}{$\begin{array}{l}\text { Soil depth } \\
\text { (cm) }\end{array}$} & \multicolumn{3}{|c|}{ Particle size distribution \% } & \multirow{2}{*}{$\begin{array}{c}\begin{array}{c}\text { Soil } \\
\text { texture }\end{array} \\
\end{array}$} & \multicolumn{3}{|c|}{ Available nutrients (mg/kg soil) } & \multirow{2}{*}{$\begin{array}{c}\text { Field } \\
\text { capacity } \%\end{array}$} & \multirow{2}{*}{$\begin{array}{c}\text { Wilt } \\
\text { point } \%\end{array}$} & \multirow{2}{*}{$\begin{array}{c}\text { Available } \\
\text { water }\end{array}$} \\
\hline & Sand & Silt & Clay & & $\mathbf{N}$ & $\mathbf{P}$ & $\mathbf{K}$ & & & \\
\hline $0-15$ & 90.5 & 5.5 & 4.0 & & 12.55 & 8.14 & 80.10 & 12.3 & 5.3 & 7.0 \\
\hline $15-30$ & 91.3 & 4.7 & 4.0 & Sandy & 10.11 & 7.15 & 60.17 & 12.0 & 5.2 & 6.8 \\
\hline $30-45$ & 92.6 & 2.9 & 4.5 & & 6.45 & 5.75 & 40.70 & 11.1 & 4.3 & 6.8 \\
\hline Soil depth & $\mathrm{BD}$ & $\mathrm{EC}$ & $\mathrm{nH}$ & \multicolumn{7}{|c|}{ Soluble cations and anions (meq/l) } \\
\hline$(\mathrm{cm})$ & $\left(\mathrm{g} / \mathrm{cm}^{3}\right)$ & $\mathrm{ds} / \mathrm{cm}$ & $\mathrm{pH}$ & $\mathrm{Ca}^{+2}$ & $\mathrm{Mg}^{+2}$ & $\mathrm{Na}^{+}$ & $\mathrm{K}^{+}$ & $\mathrm{HCO}_{3}^{-}$ & $\mathrm{SO}_{4}^{-2}$ & $\mathrm{Cl}^{-}$ \\
\hline $0-15$ & 1.43 & 0.87 & 8.6 & 2.80 & 0.85 & 3.53 & 1.30 & 1.57 & 2.62 & 4.29 \\
\hline $15-30$ & 1.60 & 0.89 & 8.8 & 2.91 & 0.90 & 3.62 & 1.41 & 1.69 & 2.75 & 4.40 \\
\hline $30-45$ & 1.71 & 0.91 & 8.8 & 3.01 & 0.93 & 3.70 & 1.46 & 1.75 & 2.64 & 4.71 \\
\hline
\end{tabular}

Applied Irrigation Water:

Evapotranspiration $\left(\mathrm{ET}_{0}\right)$ was calculated according to Penman-Monteith equation as follows:

$$
E T o=\frac{0.408 \Delta(R n-G)+\gamma[900 /(T+273)] U_{2}\left(e_{s}-e_{a}\right)}{\Delta+\gamma\left(1+0.34 U_{2}\right)}
$$

\section{Where:}

$\Delta=$ slope of vapor pressure and temperature curve $\left(\mathrm{kPa}{ }^{\circ} \mathrm{C}-1\right) . \mathrm{Rn}=$ net radiation (MJ m-2d-1). $\mathrm{G}=$ soil heat flux (MJ m-2d-1). $\gamma=$ psychrometric constant $\left(\mathrm{kPa}{ }^{\circ} \mathrm{C}-1\right) . \mathrm{T}=$ mean daily air temperature at 2 $\mathrm{m}$ height $\left({ }^{\circ} \mathrm{C}\right) . \quad \mathrm{U}_{2}=$ wind speed at $2 \mathrm{~m}$ height $(\mathrm{ms}-1) . \quad \mathrm{e}_{\mathrm{s}}-\mathrm{e}_{\mathrm{a}}=$ vapor pressure deficit $(\mathrm{kPa})$.

The input parameters which needed to calculate $\mathrm{ET}_{0}$ using the CROPWAT model (Smith, 1992) are temperature, relative humidity, sunshine hours, and wind speed. The data from Wadi- El-Natrun Station were used in this study.
The amounts of applied irrigation water were calculated according to the equation given by Vermeiren and Jopling (1984) as follows:

\section{Where:}

$$
A I W=\frac{E T o \times K c I}{E a(1-L R)}
$$

$\mathrm{AIW}=$ depth of applied irrigation water in $\mathrm{mm}$. $\mathrm{ET}_{0}=$ evapotranspiration, $\mathrm{mmd}^{-1} . \mathrm{Kc}=$ crop coefficient (for sugar beet crop as reported by Allen et al., 1998). I= irrigation intervals (days). $\mathrm{Ea}=$ irrigation application efficiency of the drip irrigation system. L.R = leaching requirements.

Irrigation time for drip irrigation system was determined before an event by measuring the actual emitter discharges according the equation given by Ismail (2002) as follows: 


$$
t=\frac{A I W \times A}{q}
$$

Where:

$\mathrm{t}=$ irrigation time $(\mathrm{h}) . \mathrm{A}=$ wetted area $\left(\mathrm{cm}^{2}\right)$.

$\mathrm{q}=$ emitter discharge $(\mathrm{L} / \mathrm{h})$.

$\mathrm{AIW}=$ applied irrigation water $(\mathrm{cm})$.

Table 2. Sugar beet crop coefficient.

\begin{tabular}{lcc}
\hline Growth stage & Days & Crop coefficient (Kc) \\
\hline Initial stage & 30 & 0.35 \\
Development & 60 & 1.2 \\
Midi stage & 60 & 0.7 \\
End stage & 40 & 0.5 \\
Total & 190 & -- \\
\hline
\end{tabular}

The total amount of applied irrigation water for 60,80 , and $100 \%$ of ET0 irrigation treatments were $469.8,626.4$ and $783.0 \mathrm{~mm}$, respectively, in the $2013 / 14$ season, and were 459.3, 612.4, and $765.5 \mathrm{~mm}$, respectively, in 2014/15 season.

Data recorded:-

1. Weed survey:

At harvest, in each plot, weeds were hand pulled from one square meter chosen at random then identified and classified to annual grassy, broad-leaved weeds and their total.

\section{Sugar beet yield and juice quality:}

At harvest, sugar beet plants in each the whole plot were harvested and weighted to determine the following traits:-

1- Top yield (ton/fed). 2- Root yield (ton/fed). 3- Gross sugar yield, GSY $($ ton/fed $)=$ root yield $($ ton/fed) $\mathrm{x}$ sugar percentage. 4- Total soluble solids (TSS \%). 5- Sucrose $\%$ : Juice sugar content of each treatment was estimated in fresh samples of sugar beet root by using Saccharometer according to the method described by A.O.A.C. (Ahadi and Sobhani, 2005). 6- Purity percentage: It was estimated according to the following formula:

$$
\text { Purity }, \%=\frac{\text { Sucrose } \%}{\text { TSS \% }} \times 100
$$

At harvest, sugar beet plants of each plot were up-rooted, topped, cleaned and weighed to determine root yield as ton/fed, sugar yield (ton/fed) was estimated after taking subsamples from each plot (10 roots) and fully cleaned roots and sent to Nile Sugar Company Lab and Sugar Crops Institute at Nubaria to determine physiological and chemical characters. Preparation of thick juice from sugar beet sub-samples (each sample was $10 \mathrm{~kg}$ of beet) on a laboratory scale, according to the method of Wieninger and Kubadinow (1971).

\section{Irrigation Water Use Efficiency (IWUE):}

Irrigation water use efficiency was calculated according to Jensen (1983) as the following equations:

IWUE $_{\text {root yield }}\left(\mathrm{kg} / \mathrm{m}^{3}\right)=\operatorname{root}$ yield $(\mathrm{kg} / \mathrm{fed}) /$ applied irrigation water $\left(\mathrm{m}^{3} / \mathbf{f e d}\right)$

IWUE sugar yield $\left(\mathrm{kg} / \mathrm{m}^{3}\right)=$ sugar yield $(\mathrm{kg} / \mathrm{fed}) /$ applied

\section{Statistical Analysis}

$$
\text { irrigation water }\left(\mathrm{m}^{3} / \mathrm{fed}\right)
$$

All data were statistically analyzed according to technique of analysis of variance (ANOVA) for the split-plot design as mentioned by Gomez and Gomez (1984) by means of "SAS" and SPSS computer software packages Duncan multiple range test was used for compare among treatments mean (Duncan, 1955).

\section{RESULTS AND DISCUSSION}

During the two growing seasons of sugar beet crop the major weed species at the experimental sites were Avena spp., Polypogon monspelinsis and Phalaris spp. as annual grassy weeds, and Cichorium endivia L., Beta vulgaris L., Chenopodium album L., Sonchus oleraceus L., Medicago polymorpha L., Melilotus indica L., Anagallis arvensis, Ammi majus L., Emex spinosus L., Senecio glaucus L. and Rumex dentatus L. as annual broad-leaved weeds.

\section{A. Effect of deficit irrigation: \\ I- On weeds $\left(\mathrm{g} / \mathrm{m}^{2}\right)$ :}

Table 3 showed that the highest significant reduction in the fresh weight of grassy, broad-leaved and total weeds was obtained by irrigation at $60 \%$ evapotranspiration $\left(\mathrm{ET}_{0}\right)$ treatment $(14.8,16.0$ and $15.6 \%$, respectively, in 2013/14 season and 25.0, 13.6 and $17.3 \%$ in 2014/15 season, respectively, as compared to $100 \% \mathrm{ET}_{0}$ treatment. This may be due to that usually, the water restriction initially affects the most sensitive organs, such as the leaves, inflorescences and roots, regardless of the studied species. Patterson (1995) and Lima et al. (2016) who mentioned that the water deficit caused a reduction on the leaf dry matter and consequently total dry matter accumulation of some weed species.

Table 3. Effect of irrigation water treatments on the

\begin{tabular}{|c|c|c|c|c|c|c|}
\hline \multirow[b]{2}{*}{$\begin{array}{l}\mathbf{E T}_{0} \\
\% \\
\text { treatments }\end{array}$} & \multicolumn{3}{|c|}{$2013 / 2014$ season } & \multicolumn{3}{|c|}{2014 / 2015 season } \\
\hline & $\begin{array}{l}\text { Grassy } \\
\text { weeds } \\
\left(\mathrm{g} / \mathrm{m}^{2}\right)\end{array}$ & $\begin{array}{l}\text { Broad- } \\
\text { leaved } \\
\text { weeds } \\
\left(\mathrm{g} / \mathrm{m}^{2}\right) \\
\end{array}$ & $\begin{array}{c}\text { Total } \\
\text { weeds } \\
\left(\mathrm{g} / \mathrm{m}^{2}\right)\end{array}$ & $\begin{array}{l}\text { Grassy } \\
\text { weeds } \\
\left(\mathrm{g} / \mathrm{m}^{2}\right)\end{array}$ & $\begin{array}{l}\text { Broad- } \\
\text { leaved } \\
\text { weeds } \\
\left(\mathrm{g} / \mathrm{m}^{2}\right) \\
\end{array}$ & $\begin{array}{r}\text { Total } \\
\text { weeds } \\
\left(\mathrm{g} / \mathrm{m}^{2}\right)\end{array}$ \\
\hline 60 & 200.8 & $461.1 \mathrm{c}$ & 661 & & $543.4 \mathrm{c}$ & 770. \\
\hline 80 & 233 & & 20 & & & \\
\hline 100 & 235.6 & $548.8 \mathrm{a}$ & $784.4 \mathrm{a}$ & $302.3 \mathrm{a}$ & $628.7 \mathrm{a}$ & $931.0 \mathrm{a}$ \\
\hline
\end{tabular}
fresh weight of annual weeds $\left(\mathrm{g} / \mathrm{m}^{2}\right)$ in 2013/2014 and 2014/2015 winter seasons.

\section{II- On sugar beet yield and juice quality:}

The effects of irrigation water deficit treatments on the yield and juice quality of sugar beet are presented in Table 4 showed that irrigation water at $60 \%$ of $\mathrm{ET}_{0}$ significantly reduced the sugar beet top yield (ton/fed) by 21.4 and $25.5 \%$ in the first and second seasons, respectively, as compared to $100 \% \mathrm{ET}_{0}$. Irrigation at 60 $\% \mathrm{ET}_{0}$ gave the highest value of root yield (20.18 and 20.02 ton/fed) in the first and second seasons, respectively. The percentage increase of root yield of sugar beet at $60 \%$ of $\mathrm{ET}_{0}$ was account as 58.8 and $60.2 \%$ than the treatment of $100 \%$ of $\mathrm{ET}_{0}$ in the two seasons, respectively. These results are in agreement with those of Emara (1996) and Abdel-Nasser et al. (2014).

- Irrigation at $60 \%$ and $80 \% \mathrm{ET}_{0}$ gave the highest significant values of gross sugar yield (3.36, 3.06 and $3.11,3.13$ ton/fed) in the two seasons, respectively. The increase in sugar yield was due to both increase in sugar content and root yield in which sugar yield was adversely affected by water deficit. Increasing the impurities in the root of stressed plants decreased extraction of sugar. So, deficit irrigation improved sugar beet quality by reducing these impurities (Abdel-Nasser et al., 2014). Irrigation at $60 \%$ and 80 $\% \mathrm{ET}_{0}$ gave the highest values of TSS $(20.62,20.57$ and $20.42,20.52 \%$ ) in 2013/14 and 2014/15 seasons, 
respectively. Irrigation at $60 \%$ and $80 \% \mathrm{ET}_{0}$ gave the highest significant values of sucrose \% in 2013/14 and 2014/15 seasons. Similar results were obtained by
Kirda (2002), meanwhile purity \% did not affect by any water irrigation treatments (Osman et al., 2005 showed the similar results).

Table 4. Effect of irrigation treatments on the yield and juice quality of sugar beet in 2013/2014 and 2014/2015 winter seasons.

\begin{tabular}{|c|c|c|c|c|c|c|}
\hline ET $_{0} \%$ treatments & Top yield (ton/fed) & Root yield (ton/fed) & Gross sugar yield (ton/fed) & TSS \% & Sucrose\% & Purity \% \\
\hline \multicolumn{7}{|c|}{$2013 / 2014$ season } \\
\hline 60 & $5.33 \mathrm{~b}$ & $20.18 \mathrm{a}$ & $3.36 \mathrm{a}$ & $20.62 \mathrm{a}$ & $16.75 \mathrm{a}$ & $81.73 \mathrm{a}$ \\
\hline 80 & $6.00 \mathrm{~b}$ & $17.70 \mathrm{~b}$ & $3.06 \mathrm{a}$ & $20.57 \mathrm{a}$ & $17.27 \mathrm{a}$ & $81.36 \mathrm{a}$ \\
\hline 100 & $6.78 \mathrm{a}$ & $12.71 \mathrm{c}$ & $2.03 \mathrm{~b}$ & $19.60 \mathrm{~b}$ & $15.99 \mathrm{~b}$ & $80.94 \mathrm{a}$ \\
\hline \multicolumn{7}{|c|}{2014 / 2015 season } \\
\hline 60 & $5.49 \mathrm{~b}$ & $20.02 \mathrm{a}$ & $3.11 \mathrm{a}$ & $20.42 \mathrm{a}$ & $17.10 \mathrm{a}$ & $82.04 \mathrm{a}$ \\
\hline 80 & $5.72 \mathrm{~b}$ & $17.38 \mathrm{~b}$ & & & $17.57 \mathrm{a}$ & $82.25 \mathrm{a}$ \\
\hline 100 & $7.37 \mathrm{a}$ & $12.50 \mathrm{c}$ & $2.22 \mathrm{~b}$ & $20.06 \mathrm{~b}$ & $16.05 \mathrm{~b}$ & $81.44 \mathrm{a}$ \\
\hline
\end{tabular}

\section{B. Effect of weeds removal intervals treatments:}

I- On weeds $\left(\mathrm{g} / \mathrm{m}^{2}\right)$ :

The effect of weeds removal intervals treatments on the fresh weight of grassy, broad-leaved and total weeds $(\mathrm{g} / \mathrm{m} 2)$ were presented in Table 5. The data illustrated that the dominant annual weeds in this study were the broadleaf weeds with infestation rates $3.0 \mathrm{~kg}$ and $3.5 \mathrm{~kg}$ fresh weight $/ \mathrm{m} 2$ in the first and second seasons, respectively. Whilst, the infestation rate of grassy weeds was 1.3 and $1.4 \mathrm{~kg}$ fresh weight $/ \mathrm{m} 2$ in the both seasons, respectively. In the both seasons, the reduction percentage of the fresh weight broadleaf weeds, grasses and their total under all weed free and weed infestation intervals treatments were more $90 \%$ as compared with weed infestation for the whole season with exception of weed free for 3 weeks only, which reached to $68.5,69.6$ and $69.3 \%$, respectively, in the first season and $65.4,68.8$ and $76.8 \%$, respectively, in second season. These results are in agreed with Kropff et al., 1992 and Salehi et al., 2006.

Table 5. Effect of weeds removal interval treatments on the fresh weight annual weeds $\left(\mathrm{g} / \mathrm{m}^{2}\right)$ in $2013 / 2014$ and 2014/2015 winter seasons.

\begin{tabular}{|c|c|c|c|c|c|c|}
\hline \multirow{2}{*}{$\begin{array}{l}\text { Weed removal or } \\
\text { infestation intervals }\end{array}$} & \multicolumn{3}{|c|}{2013 / 2014 season } & \multicolumn{3}{|c|}{2014 / 2015 season } \\
\hline & $\begin{array}{c}\text { Grassy weeds } \\
\left(\mathrm{g} / \mathbf{m}^{2}\right)\end{array}$ & $\begin{array}{l}\text { Broad-leaved } \\
\text { weeds }\left(\mathrm{g} / \mathbf{m}^{2}\right)\end{array}$ & $\begin{array}{c}\text { Total weeds } \\
\left(\mathrm{g} / \mathrm{m}^{2}\right)\end{array}$ & $\begin{array}{c}\text { Grassy weeds } \\
\left(\mathrm{g} / \mathrm{m}^{2}\right)\end{array}$ & $\begin{array}{l}\text { Broad-leaved } \\
\text { weeds }\left(g / \mathbf{m}^{2}\right)\end{array}$ & $\begin{array}{l}\text { Total weeds } \\
\left(\mathrm{g} / \mathrm{m}^{2}\right)\end{array}$ \\
\hline Weed free for 3 WAP ${ }^{(1)}$ & $403.2 \mathrm{~b}$ & $921.8 \mathrm{~b}$ & $1324 \mathrm{~b}$ & $477 \mathrm{~b}$ & $1105 \mathrm{~b}$ & $1582 \mathrm{~b}$ \\
\hline Weed free for 6 WAP & $124.0 \mathrm{c}$ & $200.4 \mathrm{c}$ & $324.4 \mathrm{c}$ & $243.9 \mathrm{c}$ & $278.6 \mathrm{c}$ & $522.5 \mathrm{c}$ \\
\hline Weed free for 9 WAP & $43.7 \mathrm{c}$ & $149.6 \mathrm{c}$ & $193.3 \mathrm{c}$ & $49.7 \mathrm{~d}$ & $169.5 \mathrm{c}$ & $219.2 \mathrm{c}$ \\
\hline Weed free for 12 WAP & $26.9 \mathrm{c}$ & $101.8 \mathrm{c}$ & $128.7 \mathrm{c}$ & $31.3 \mathrm{~d}$ & $117.7 \mathrm{c}$ & $149.0 \mathrm{c}$ \\
\hline Weed free for the whole season & $34.4 \mathrm{c}$ & $68.7 \mathrm{c}$ & $103.1 \mathrm{c}$ & $40.6 \mathrm{~d}$ & $80.5 \mathrm{c}$ & $121.1 \mathrm{c}$ \\
\hline Weed infestation for 3 WAP & $44.5 \mathrm{c}$ & $81.0 \mathrm{c}$ & $125.4 \mathrm{c}$ & $50.9 \mathrm{~d}$ & $94.0 \mathrm{c}$ & $144.9 \mathrm{c}$ \\
\hline Weed infestation for 6 WAP & $73.5 \mathrm{c}$ & $151.0 \mathrm{c}$ & $224.4 \mathrm{c}$ & $84.6 \mathrm{~d}$ & $182.5 \mathrm{c}$ & $267.2 \mathrm{c}$ \\
\hline Weed infestation for 9 WAP & $97.5 \mathrm{c}$ & $112.0 \mathrm{c}$ & $269.5 \mathrm{c}$ & $123.1 \mathrm{~cd}$ & $131.3 \mathrm{c}$ & $254.4 \mathrm{c}$ \\
\hline Weed infestation for 12 WAP & $106.3 \mathrm{c}$ & $192.8 \mathrm{c}$ & $299.1 \mathrm{c}$ & $133.3 \mathrm{~cd}$ & $155.1 \mathrm{c}$ & $288.4 \mathrm{c}$ \\
\hline Weed infestation for the whole season & $1278 \mathrm{a}$ & $3030 \mathrm{a}$ & $4308 \mathrm{a}$ & $1378 \mathrm{a}$ & $3538 \mathrm{a}$ & 4916 a \\
\hline
\end{tabular}

${ }^{(1)}$ WAP $=$ weeks after planting.

\section{II- On sugar beet yield and juice quality:}

Data in Table 6 showed that increasing weed free or weed infestation intervals from planting caused consistent significant increases in top, root and sugar yields (ton/fed) than weed infestation for the whole season. These results were true in 2013/14 and 2014/15 winter seasons, meanwhile TSS $\%$, sucrose $\%$ and purity $\%$ were not affected significantly by either early or late weed removal intervals in both season except with TSS \% in second season where the highest TSS \% were obtained by weed free for the whole season which increased by $7 \%$ than weed infestation for the whole season. Concerning the top yield per faddan, both weed free for the whole season and weed free for 12 WAP increased top yield by 138.3 and $118.6 \%$ in $2013 / 14$ season and by 98.7 and $95 \%$ in $2014 / 15$ season, respectively, as compared to weed infestation for the whole season. Concerning the sugar beet yield (ton/fed), weed free for the whole season significantly increased the sugar beet yield by $302.5 \%$ in 2013/14 season, whereas, in 2014/15 season weed free for the whole season, weed free 12 WAP and weed infestation for 3 WAP increased the root yield by $311.3,305.4$ and $292.7 \%$, respectively, as compared to weed infestation for the whole season (weedy check). Also, weed free for the whole season, weed free 12 WAP and weed infestation for 3 WAP increased gross sugar yield by $353.8,333.7$ and $291.3 \%$, respectively, in 2013/14 season, and by $288.7,258.9$ and $228.2 \%$, respectively, in 2014/15 season, as compared to weed infestation for the whole season (weedy check). Similar findings were obtained by Jursik et al., 2008; Salehi et al., 2006; Mobarak et al., 2012 and Fayed et al., 1999.

C. The interaction between deficit water irrigation and weeds removal intervals treatments:

Table 7 showed that the effect of irrigation water $\mathrm{x}$ weeds removal interval treatments interaction was statistically significant, in both seasons, on grassy, broadleaved and total weeds fresh weights, root and sugar yield (ton/fed). The highest significantly values of the fresh weights of grassy, broad-leaved and total weeds were recorded from weed infestation for the whole season treatment, in the two seasons, regardless of the Irrigation water amount. Wherever, the lowest values of these characters, in the two seasons, were obtained from the low irrigation water treatment $\left(60 \% \mathrm{ET}_{0}\right)$ under all weed removal interval treatments. These results may be due to deficit irrigation from 100 to $60 \% \mathrm{ET}_{0}$ reduce the number and growth of weeds. Concerning the root yield (ton/fed), the highest significantly values of sugar beet yield were 
recorded from weed free for the whole season and weed free for 12 WAP treatments at $60 \% \mathrm{ET}_{0}$ and weed free for whole season, weed free for 12 WAP and weed infestation for $3 \mathrm{WAP}$ at $80 \% \mathrm{ET}_{0}$ in the two seasons. Wherever, the lowest values of root yield were obtained from the high irrigation water treatment $\left(100 \% \mathrm{ET}_{0}\right)$ under all weeds removal time treatments, in both seasons. These results may be due to deficit irrigation from 100 to $60 \% \mathrm{ET}_{0}$ cause reduction on the growth of weeds and therefore reduction on infestation of weeds with sugar beet plants which leads to increasing on sugar beet plants growth and yield. On the other hand, the highest significantly values of gross sugar yield (ton/fed) were recorded from weed free for the whole season and weed free for 12 WAP treatments at 60 and $80 \%$ $\mathrm{ET}_{0}$ in the two seasons. Wherever, the lowest values of gross sugar yield were obtained from the high irrigation water treatment $\left(100 \% \mathrm{ET}_{0}\right)$ under all weeds removal time treatments, in both seasons.

Table 6. Effect of weeds removal interval treatments on the yield and juice quality of sugar beet in 2013/2014 and 2014/2015 winter seasons.

\begin{tabular}{|c|c|c|c|c|c|c|}
\hline $\begin{array}{l}\text { Weed removal or } \\
\text { infestation intervals }\end{array}$ & $\begin{array}{l}\text { Top yield } \\
\text { (ton/fed) }\end{array}$ & $\begin{array}{c}\text { Root yield } \\
\text { (ton/fed) }\end{array}$ & $\begin{array}{l}\text { Gross sugar } \\
\text { yield (ton/fed) }\end{array}$ & $\begin{array}{c}\text { TSS } \\
\%\end{array}$ & $\begin{array}{c}\text { Sucrose } \\
\%\end{array}$ & $\begin{array}{c}\text { Purity } \\
\%\end{array}$ \\
\hline \multicolumn{7}{|c|}{$2013 / 2014$ season } \\
\hline Weed free for 3 WAP $^{(1)}$ & $5.88 \mathrm{~b}$ & $7.86 \mathrm{ef}$ & $1.18 \mathrm{ef}$ & $20.50 \mathrm{a}$ & $16.11 \mathrm{a}$ & $82.06 \mathrm{a}$ \\
\hline Weed free for 6 WAP & $6.04 \mathrm{~b}$ & $16.11 \mathrm{~d}$ & $2.66 \mathrm{~d}$ & $20.83 \mathrm{a}$ & $16.98 \mathrm{a}$ & $81.82 \mathrm{a}$ \\
\hline Weed free for 9 WAP & $6.72 \mathrm{~b}$ & $21.05 \mathrm{~b}$ & $3.99 \mathrm{c}$ & $20.92 \mathrm{a}$ & $16.10 \mathrm{a}$ & $82.79 \mathrm{a}$ \\
\hline Weed free for 12 WAP & $8.11 \mathrm{a}$ & $26.49 \mathrm{~b}$ & $4.51 \mathrm{ab}$ & $20.83 \mathrm{a}$ & $17.23 \mathrm{a}$ & $81.85 \mathrm{a}$ \\
\hline Weed free for the whole season & $8.84 \mathrm{a}$ & $27.57 \mathrm{a}$ & $4.72 \mathrm{a}$ & $20.58 \mathrm{a}$ & $17.10 \mathrm{a}$ & $82.67 \mathrm{a}$ \\
\hline Weed infestation for $3 \mathrm{WAP}$ & $6.79 \mathrm{~b}$ & $25.67 \mathrm{~b}$ & $4.07 \mathrm{ab}$ & $20.81 \mathrm{a}$ & $16.75 \mathrm{a}$ & $81.25 \mathrm{a}$ \\
\hline Weed infestation for $6 \mathrm{WAP}$ & $6.21 \mathrm{~b}$ & $18.24 \mathrm{c}$ & $3.04 \mathrm{~d}$ & $20.62 \mathrm{a}$ & $16.71 \mathrm{a}$ & $82.48 \mathrm{a}$ \\
\hline Weed infestation for 9 WAP & $4.16 \mathrm{c}$ & $10.35 \mathrm{e}$ & $1.56 \mathrm{e}$ & $20.52 \mathrm{a}$ & $16.06 \mathrm{a}$ & $82.62 \mathrm{a}$ \\
\hline Weed infestation for 12 WAP & $3.91 \mathrm{c}$ & $8.46 \mathrm{f}$ & $1.37 \mathrm{ef}$ & $20.46 \mathrm{a}$ & $17.15 \mathrm{a}$ & $81.83 \mathrm{a}$ \\
\hline Weed infestation for the whole season & $3.71 \mathrm{c}$ & $6.85 \mathrm{f}$ & $1.04 \mathrm{f}$ & $20.39 \mathrm{a}$ & $16.42 \mathrm{a}$ & $82.05 \mathrm{a}$ \\
\hline \multicolumn{7}{|c|}{$2014 / 2015$ season } \\
\hline Weed free for 3 WAP & $5.50 \mathrm{de}$ & $8.71 \mathrm{~d}$ & $1.43 \mathrm{~d}$ & $20.42 \mathrm{ab}$ & $16.48 \mathrm{a}$ & $80.90 \mathrm{a}$ \\
\hline Weed free for 6 WAP & $6.78 \mathrm{bc}$ & $17.24 \mathrm{c}$ & $2.92 \mathrm{c}$ & $20.62 \mathrm{ab}$ & $16.99 \mathrm{a}$ & $82.00 \mathrm{a}$ \\
\hline Weed free for 9 WAP & $7.61 \mathrm{bc}$ & $23.09 \mathrm{~b}$ & $3.98 \mathrm{~b}$ & $21.17 \mathrm{a}$ & $16.17 \mathrm{a}$ & $82.94 \mathrm{a}$ \\
\hline Weed free for 12 WAP & $7.80 \mathrm{ab}$ & $26.15 \mathrm{a}$ & $4.45 \mathrm{ab}$ & $20.67 \mathrm{ab}$ & $16.97 \mathrm{a}$ & $81.43 \mathrm{a}$ \\
\hline Weed free for the whole season & $7.95 \mathrm{a}$ & $26.53 \mathrm{a}$ & $4.82 \mathrm{a}$ & $21.42 \mathrm{a}$ & $16.73 \mathrm{a}$ & $83.74 \mathrm{a}$ \\
\hline Weed infestation for $3 \mathrm{WAP}$ & $6.52 \mathrm{~cd}$ & $25.33 \mathrm{a}$ & $4.34 \mathrm{ab}$ & $20.40 \mathrm{ab}$ & $17.04 \mathrm{a}$ & $82.42 \mathrm{a}$ \\
\hline Weed infestation for 6 WAP & $6.84 \mathrm{bc}$ & $16.52 \mathrm{c}$ & $2.56 \mathrm{c}$ & $20.04 \mathrm{ab}$ & $16.15 \mathrm{a}$ & $81.74 \mathrm{a}$ \\
\hline Weed infestation for 9 WAP & 4.71ef & $8.77 \mathrm{~d}$ & $1.45 \mathrm{~d}$ & $20.67 \mathrm{ab}$ & $17.00 \mathrm{a}$ & $81.04 \mathrm{a}$ \\
\hline Weed infestation for 12 WAP & $4.21 \mathrm{f}$ & $7.60 \mathrm{de}$ & $1.01 \mathrm{~d}$ & $20.50 \mathrm{ab}$ & $17.14 \mathrm{a}$ & $80.55 \mathrm{a}$ \\
\hline Weed infestation for the whole season & $4.00 \mathrm{f}$ & $6.45 \mathrm{e}$ & $1.24 \mathrm{~d}$ & $19.92 \mathrm{~b}$ & $16.75 \mathrm{a}$ & $82.34 \mathrm{a}$ \\
\hline
\end{tabular}

${ }^{(1)}$ WAP $=$ weeks after planting.

\section{Irrigation Water Use Efficiency (IWUE):}

The effect of deficit irrigation on water use efficiency (IWUE) values for both root and gross sugar yields are presented in Table 8 showed that decreasing the amount of irrigation water from $100 \%$ to $80 \%$ and $60 \%$ of $\mathrm{ET}_{0}$ increased IWUE of root and sugar yield. The highest IWUE root yield values of 7.50 and $7.95 \mathrm{~kg}$ root $/ \mathrm{m}^{3}$ of applied water were obtained from the lowest $\mathrm{ET}_{0}$ irrigation $(60 \%)$ during 2013/14 and 2014/15 seasons, respectively. While, the highest IWUE sugar yield values of 1.23 and $1.34 \mathrm{~kg}$ sugar $/ \mathrm{m}^{3}$ of applied water were obtained from the same irrigation treatment $\left(60 \%\right.$ of $\left.\mathrm{ET}_{0}\right)$ in the first and second growing seasons, respectively. These findings are in line with those reported by Awad et al. (2003), Osman et al. (2005), Esmaeili (2011). On the other hand, the highest IWUE for root yield values $\left(\mathrm{kg}\right.$ root $\left./ \mathrm{m}^{3}\right)$ were obtained from weed free for whole seasons ( 11.19 and $\left.10.83 \mathrm{~kg} / \mathrm{m}^{3}\right)$, during 2013/14 and 2014/15 seasons, respectively. Also, the highest IWUE for sugar yield values were obtained from weed free for whole seasons (1.83 and $1.84 \mathrm{~kg}$ sugar $\left./ \mathrm{m}^{3}\right)$ in 2013/14 and 2014/15 seasons, respectively. These results show what the weed removal from sugar beet fields can raise water efficiency by $240-320 \%$ as compared to leave the weeds to compete sugar beet plants for whole season. From these results also, to obtain maximum water use efficiency must be irrigated at $60 \%$ of $\mathrm{ET}_{0}$ and save the sugar beet crop without weeds for the whole season, while $100 \%$ of $\mathrm{ET}_{0}$ and weed infestation for the whole season decreased water use efficiency to minimum values.

\section{E. Estimation yield losses and the critical period of weed infestation to sugar beet yield:}

Data presented in Table 6 and Figure 1 showed the biological response curve to weed removal intervals on root and sugar yield (ton/fed) and revealed that the losses in either root or gross sugar yield. In general, there is no significant differences in either root or sugar yield (ton/fed) for weed free period for the whole season or weed free for 12 weeks from planting in both seasons, meaning that sugar beet plants can tolerate weeds which germinate after this period until harvest. On the other hand, the yields of root or sugar per faddan from weed free treatments didn't affect significantly than their corresponding yields of weed infestation treatments for three weeks or weed infestation for the whole season meaning that sugar beet plants can tolerate weeds in this period, meaning that both root sugar beet and sugar yield can be sensitive to weed infestation through the period of from 3- 12 weeks and can be considered that weeds should be controlled through the critical period by hoeing or herbicides combinations through this prolonged period of weed competition to maintain sugar beet potential productivity. These results are agreed with those obtained by Odero et al. 2009 and Odero et al. 2010. Zindahl (1979) mentioned that because sugar beet leaf canopy forms slowly, entire crops can be decimated by competition from certain weed species and weeds must begin by the time sugar beet have four to six true leaves and yield can be depressed 120 to $150 \mathrm{~kg} / \mathrm{ha}$ for each day weeds remain beyond this growth stage. He 
mentioned that weeds need to be controlled until 10 to 12 true leaves and he mentioned that sugar beets can tolerate

early weed competition until 4 weeks from seedling and need weed free period for 6 weeks after emergence.

Table 7. Effect of irrigation water * weeds removal interval treatments interaction on the fresh weights $\left(\mathrm{g} / \mathrm{m}^{2}\right)$ of grassy, broad-leaved and total weeds in 2013/2014 and 2014/2015 winter season.

\begin{tabular}{|c|c|c|c|c|c|c|c|c|c|c|c|}
\hline \multirow[b]{2}{*}{$\begin{array}{l}\mathbf{E T}_{0} \% \\
\text { treatments }\end{array}$} & \multirow[b]{2}{*}{$\begin{array}{l}\text { Weeds removal or } \\
\text { infestation periods } \\
\text { treatments }\end{array}$} & \multicolumn{5}{|c|}{ 2013/2014 season } & \multicolumn{5}{|c|}{$2014 / 2015$ season } \\
\hline & & $\begin{array}{l}\text { Grassy } \\
\text { weeds } \\
\left(\mathrm{g} / \mathrm{m}^{2}\right)\end{array}$ & $\begin{array}{l}\text { Broad- } \\
\text { leaved } \\
\text { weeds } \\
\left(\mathrm{g} / \mathrm{m}^{2}\right) \\
\end{array}$ & $\begin{array}{l}\text { Total } \\
\text { weeds } \\
\left(\mathrm{g} / \mathrm{m}^{2}\right)\end{array}$ & $\begin{array}{c}\text { Root } \\
\text { yield } \\
\text { (ton/fed) }\end{array}$ & $\begin{array}{c}\text { Gross } \\
\text { sugar } \\
\text { yield } \\
\text { (ton/fed) }\end{array}$ & $\begin{array}{c}\text { Grassy } \\
\text { weeds } \\
\left(\mathrm{g} / \mathbf{m}^{2}\right)\end{array}$ & $\begin{array}{l}\text { Broad- } \\
\text { leaved } \\
\text { weeds } \\
\left(\mathrm{g} / \mathrm{m}^{2}\right) \\
\end{array}$ & $\begin{array}{l}\text { Total } \\
\text { weeds } \\
\left(\mathrm{g} / \mathrm{m}^{2}\right)\end{array}$ & $\begin{array}{c}\text { Root } \\
\text { yield } \\
\text { (ton/fed) }\end{array}$ & $\begin{array}{c}\text { Gross } \\
\text { sugar } \\
\text { yield } \\
\text { (ton/fed) } \\
\end{array}$ \\
\hline \multirow{10}{*}{60} & Weed free for $3 \mathrm{WAP}^{(1)}$ & 250.5 & 510.2 & 760.7 & 10.20 & 1.58 & 349.4 & 676.4 & 1025.8 & 9.53 & 1.55 \\
\hline & Weed free for 6 WAP & 123.1 & 136.9 & 260.0 & 16.44 & 2.95 & 48.8 & 154.0 & 202.8 & 17.53 & 3.15 \\
\hline & Weed free for 9 WAP & 38.6 & 75.4 & 112.0 & 27.11 & 4.71 & 43.4 & 37.5 & 80.9 & 26.92 & 4.63 \\
\hline & Weed free for 12 WAP & 21.7 & 89.8 & 111.5 & 31.76 & 5.51 & 17.4 & 99.2 & 116.7 & 30.60 & 5.35 \\
\hline & Weed free for the whole season & 29.3 & 58.6 & 87.9 & 33.25 & 5.44 & 35.0 & 69.0 & 104.0 & 32.74 & 5.82 \\
\hline & Weed infestation for 3 WAP & 37.2 & 73.3 & 110.5 & 28.46 & 4.60 & 42.2 & 86.2 & 128.5 & 24.99 & 4.05 \\
\hline & Weed infestation for 6 WAP & 63.2 & 87.9 & 151.2 & 23.17 & 3.96 & 73.2 & 123.6 & 196.8 & 15.69 & 2.52 \\
\hline & Weed infestation for 9 WAP & 136.7 & 84.8 & 221.5 & 12.92 & 1.98 & 154.0 & 107.9 & 261.9 & 9.95 & 1.87 \\
\hline & Weed infestation for 12 WAP & 154.7 & 352.4 & 507.1 & 9.68 & 1.56 & 214.2 & 522.8 & 737.0 & 7.54 & 1.18 \\
\hline & Weed infestation for the whole season & 1126.1 & 2946.4 & 4092.5 & 6.42 & 1.31 & 1206.3 & 3123.5 & 4329.8 & 8.68 & 1.40 \\
\hline \multirow{10}{*}{80} & Weed free for 3 WAP & 337.3 & 637.4 & 974.7 & 6.68 & 1.05 & 380.4 & 704.6 & 1085.0 & 8.51 & 1.40 \\
\hline & Weed free for 6 WAP & 175.8 & 325.4 & 501.2 & 15.91 & 2.64 & 209.4 & 379.2 & 588.6 & 18.51 & 2.62 \\
\hline & AP & 47.6 & 247.7 & 295.3 & 26.20 & 4.62 & & 285.3 & 3.7 & 22.30 & 3.84 \\
\hline & 12 WAP & 4.5 & 122.6 & 147.2 & 30.32 & 5.59 & & 124.6 & 159.7 & 31.80 & 5.51 \\
\hline & he whole season & 34.6 & 69.0 & 103.6 & 31.76 & 5.27 & 41.8 & 81.2 & 123.0 & 31.75 & 5.79 \\
\hline & WAP & 48.2 & 79.6 & 127.8 & 28.61 & 4.57 & 54.2 & 91.4 & 145.6 & 29.40 & 4.54 \\
\hline & WAP & 68.9 & 169.7 & 238.6 & 17.92 & 2.97 & 79.6 & 197.1 & 276.7 & 20.75 & 3.11 \\
\hline & WAP & 164.8 & 113.8 & 278.6 & 9.82 & 1.60 & 206.8 & 124.1 & 330.9 & 8.25 & 1.51 \\
\hline & 12 WAP & 171.9 & 428.9 & 600.8 & 7.57 & 1.22 & 296.5 & 590.8 & 887.3 & 6.64 & 1.00 \\
\hline & Weed & 1306.2 & 2780.4 & 4086.6 & 6.91 & 1.22 & 1417.6 & 3473.1 & 4890.7 & 7.59 & 1.27 \\
\hline \multirow{11}{*}{100} & Weed free for 3 WAP & 381.4 & 657.7 & 1039.1 & 5.44 & 1.02 & 403.1 & 734.4 & 1137.6 & 8.09 & 1.03 \\
\hline & for 6 WAP & 143.2 & 198.9 & 342.2 & 14.47 & 2.38 & 143.5 & 232.2 & 281.1 & 15.67 & 2.98 \\
\hline & or 9 WAP & 45.1 & 125.6 & 170.7 & 15.73 & 2.64 & 52.5 & 185.8 & 238.3 & 20.04 & 2.91 \\
\hline & or 12 WAP & 34.4 & 93.0 & 127.4 & 18.69 & 3.06 & 41.5 & 129.3 & 170.8 & 17.04 & 2.69 \\
\hline & r the whole season & 39.3 & 78.5 & 117.8 & 16.95 & 2.82 & 44.9 & 91.3 & 136.3 & 16.01 & 2.64 \\
\hline & Weed infestation for 3 WAP & 48.0 & 90.0 & 138.0 & 18.33 & 2.73 & 56.4 & 104.3 & 160.7 & 19.60 & 2.92 \\
\hline & Weed infestation for 6 WAP & 88.3 & 195.2 & 283.5 & 13.64 & 2.18 & 101.1 & 226.9 & 328.0 & 13.10 & 2.03 \\
\hline & Weed infestation for 9 WAP & 171.0 & 137.5 & 308.5 & 7.62 & 1.10 & 188.5 & 161.9 & 350.4 & 8.09 & 1.26 \\
\hline & Weed infestation for 12 WAP & 182.2 & 397.3 & 579.5 & 7.95 & 1.12 & 309.2 & 622.3 & 931.4 & 5.16 & 0.88 \\
\hline & Weed infestation for the whole season & 1302.1 & 3645.0 & 4947.1 & 6.02 & 1.00 & 1511.5 & 4018.1 & 5529.6 & 6.51 & 1.05 \\
\hline & 0.05 & 183.1 & 544.9 & 669.9 & 4.25 & 0.78 & 216.46 & 638.5 & 785.7 & 3.71 & 0.80 \\
\hline
\end{tabular}

WAP = weeks after planting.

Table 8. Effect of deficit water irrigation and weed removal interval treatments on irrigation water use efficiency (IWUE) of sugar beet crop during 2013/2014 and 2014/2015 winter seasons.

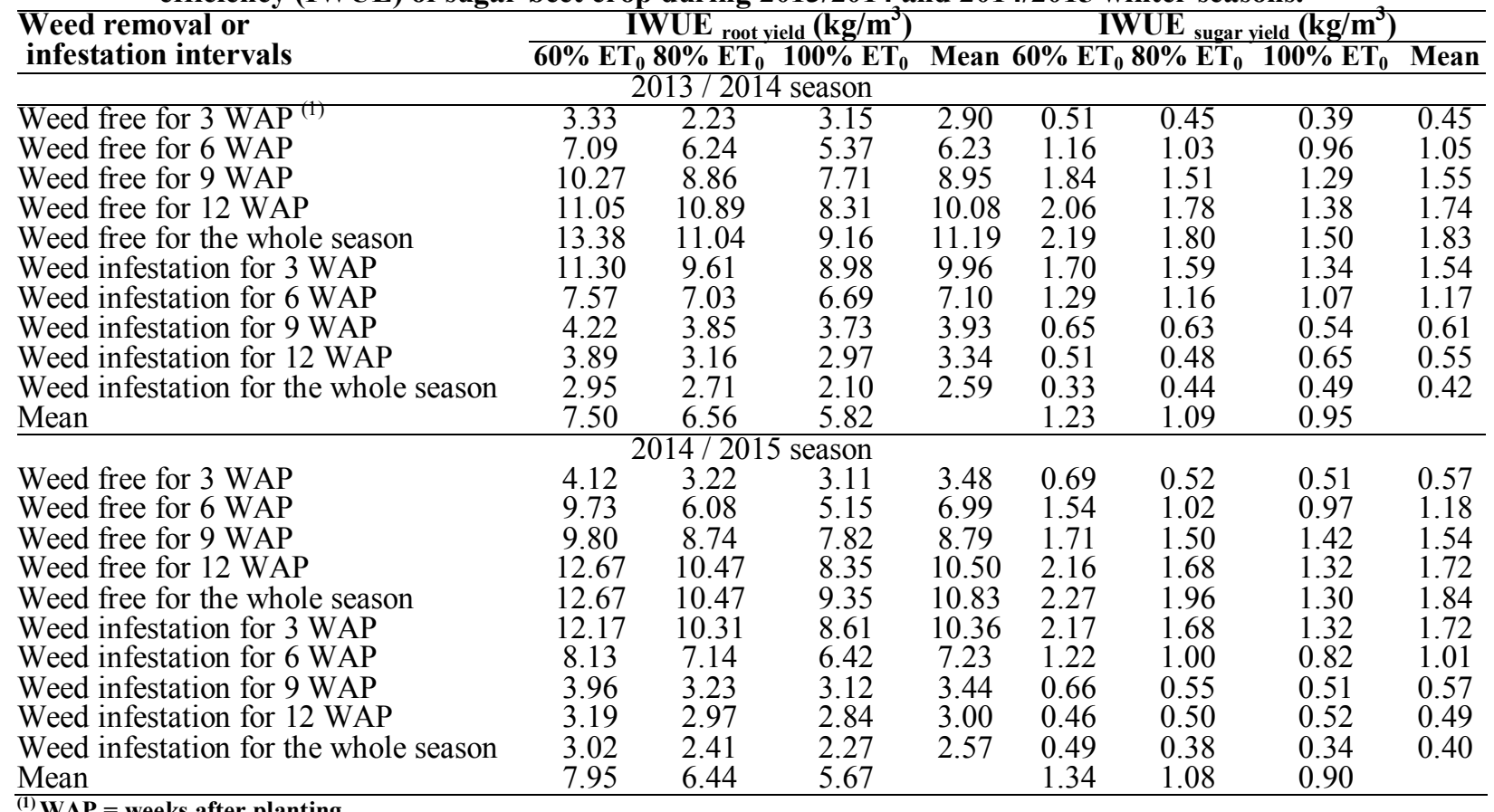




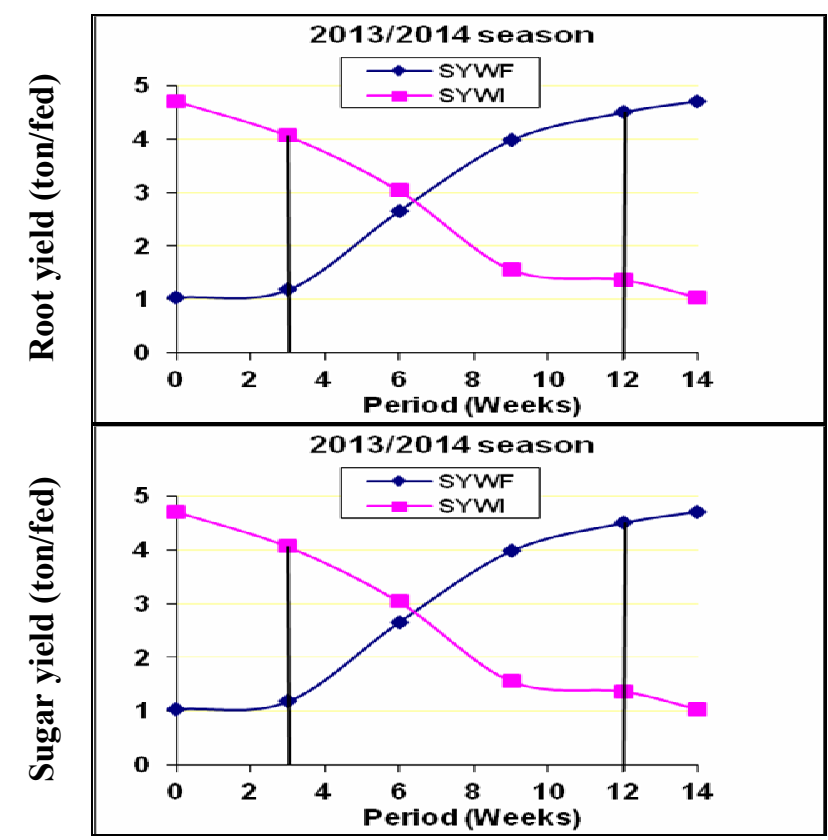

RYWF= root yield for weed free.

SYWF = sugar yield for weed free.

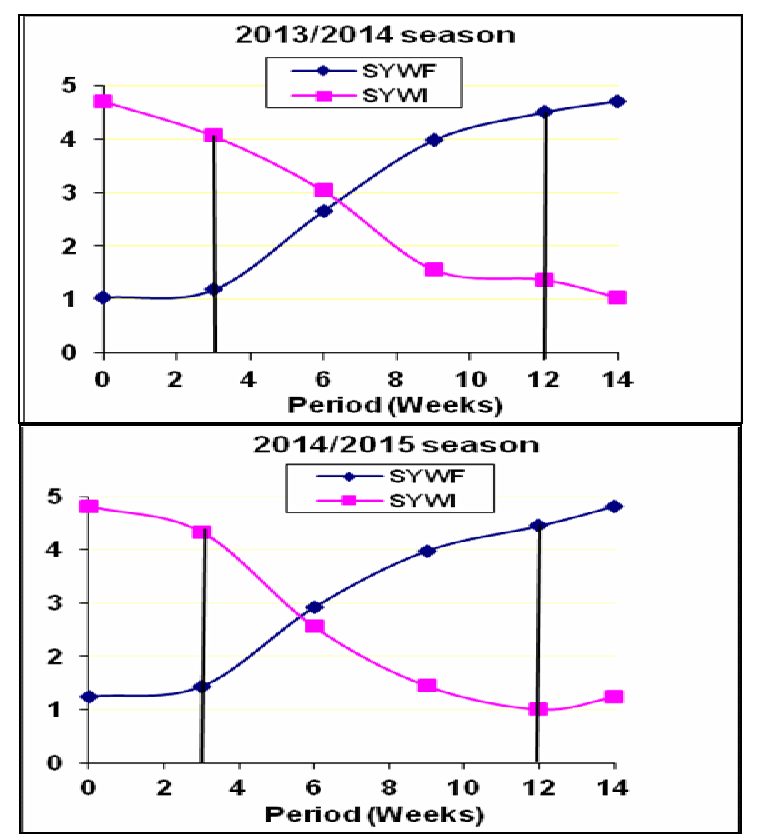

RYWI= root yield for weed infestation

SYWI= sugar yield for weed infestation

Fig. 1. Biological response curve of sugar beet yields (ton/fed) to weed infestation intervals during 2013/2014 and 2014/2015 winter seasons.

\section{CONCLUSION}

It could be concluded from this study that:

- Irrigation at $60 \%$ of evapotranspiration could be used for sugar beet grown in sandy lands under drip irrigation conditions such as El-Bostan region without decrease of root and sugar yields.

- Water use efficiency values increased slightly with increase in water deficit.

- The sugar beet plans are weak in the early stage of plant growth and it can't compete with weeds such as weed species that appear with the emergence of sugar beet.

- The critical period of weed - sugar beet interference was 3-12 weeks after planting and must needing to weed control during this period.

- The losses of sugar beet root and sugar yields in weed infestation for whole season treatment was 75 and 76 $\%$ as compared to the weed free for whole season treatment, and the loss in yield was started after 3 weeks and the maximum loss at 12 weeks after planting.

\section{REFERENCES}

Abdel-Nasser, G.; Kh. T. BenAbdalla; A. M. Osman; I. M. A. Gohar and K. M. Agami (2014). Response of sugar beet yield to deficit irrigation under drip irrigation system. J. Adv. Agric. Res., 19 (3): 442-458.

Ahadi, S. A. and M. M. Sobhani (2005). Effect of different irrigation amounts and potassium fertilizer rates on yield and quality of sugar beet and water efficiencies. J. Agric. Sci. Miyane University, 21: 4687-4699.

Alaoui, B.S.; D.L. Wyseand and A.G. Dexter (2003). Weed interference and control in sugar beet (Beta vulgaris L.) in the Gharb region of Morocco. J. of Sugar Beet Res., 40 (4): 229-249.
Allen, R. G.; L. S. Pereira; D. Raes and M. Smith (1998). Crop evapotranspiration: Guideline for computing crop water requirements. FAO No 56.

Annual report. (2018). Ministry of Agriculture and Land Reclamation, Sugar Crops Council, Annual report, January 2018.

Awad, M. A.; M. A. Mourad; K. I. El-Sayed and K. A. Allam (2003). Effects of sprinkler irrigation and nitrogen fertilization on sugar beet yield. The 11th Annual Conversion of the Misr society of Agric. Eng., Oct., 2003: 131-145.

Badr, A. A., (1987). Sugar production under sprinkler and furrow irrigation system (A comparison study). Misr J. Ag. Eng., 4 (4): 333-350.

Bucks, D. A. and S. Davis. (1986). Trickle irrigation for crop production. Netherlands, Elsevier Publications.

Deveikyte, I. and V. Seibutis. (2006). Broadleaf weeds and sugar beet response to phenmedipham, desmedipham, ethofumesate and triflusulfuronmethyl. Agron. Res., (4 Special Issue): 159-162.

Duncan, B. O. (1955). Multiple rage and multiple rage $F$ test. Biometrics, 11: 1-42.

Emara, T. K. (1996). Studies on the effect of some cultural practices on water parameters of sugar beet in North Delta Region. Ph. D. Thesis, Fac. of Agric., Mansoura Univ.

Esmaeili, M. A. (2011). Evaluation of the effects of water stress and different levels of nitrogen on sugar beet (Beta vulgaris L.). International J. of Biology, 3 (2): 89-93.

Fayed, M.T.B.; I.H. El-Geddawy and M.M. El-Zeny. (1999). Influence of weed interference on growth, yield and quality of sugar beet. Egyp. J. of Agric. Res., 77 (3): 1239-1249.

Gomez, K. A. and A. A. Gomez. (1984). Statistical procedure for agricultural research. 2 nd ed, John Wiley and sons, New York USA. 
Ismail, S.M. (2002). Design and management of field irrigation system. (in Arabic) 1st Ed. Monshat ElMaref publication Alexandria, Egypt.

Jensen, M. E. (1983). Design and operation of farm irrigation systems. Amer. Soc. Agric. Eng. Michigan, USA, p. 827.

Jursik, M.; J. Holec; J. Soukup and V. Venclova (2008). Competitive relationships between sugar beet and weeds in dependence on time of weed control. Plant, Soil and Environ., 54 (3): 108-116.

Kirda, C. (2002). Deficit irrigation scheduling based on plant growth stages showing water stress tolerance, in FAO, Deficit irrigation practices. Rome. 2002. 3-10.

Kropff, M.J.; C.J.T. Spitters; B.J. Schneiders; W. Joenije and W.D. E. Groot (1992). An ecophysiological model for interspecific infestation, applied to the Influence of Chenopodium album L. on sugar beet. Weed Res., 32(6): 451-463.

Lima, M. F. P.; J. L. D. Dombroski; F. C. L. Freitas; J. R. S. Pinto and D. V. Silva (2016). Weed growth and dry matter partition under water restriction. Planta Daninha, Vicosa-MG, 34(4): 701-707.

Mobarak, O. M. M.; Anaam H. Galal; M. S. Mekky and F. M. F. Motagally (2012). Various methods for determining the critical period of weed infestation to sugar beet. The 4th field crops conference "Field crops facing future challenges" Egyptian J. Agric. Res. 90 (4) special issue. pp 515-530.

Odero, D.C.; A.O. Mesbah; S.D. Miller and A.R. Kniss (2009). Venice mallow (Hibiscus trionum) interference in sugar beet. Weed Tech., 23 (4): 581585.
Odero, D.C.; A.O. Mesbah; S.D. iller and A.R. Kniss (2010). Wild buckwheat (Polygonum convolvulus) interference in sugar beet. Weed Tech., 24 (1): 5963.

Osman, A. M.; H. E. Khalifa; M. M. Attia and M. A. Sayed (2005). Effect of drip irrigation treatments on sugar beet yield and quality and some water relations in sandy soils. The 13th Annual Conversion of the Misr society of Agric. Eng., 22(4): 774-787.

Patterson, D. T. (1995). Effects of environmental stress on weed/crop interactions. Weed Sci., 43(4): 83-90.

Salehi, F; H. Esfandiari and H. R. Mashhadi (2006). Critical period of weed control in sugar beet in Shaheekord Region. Iranian J. of Weed Sci., 2 (2): $1-12$.

Singh, M.; M. C. Saxena; A. B. E. Abu-Irmaileh; S. A. AlThabbi and N. I. Haddad (1996). Estimation of critical period of weed control. Science, 44: 273283.

Smith, M. (1992). CROPWAT: A computer program for irrigation planning and management. FAO, Irrigation and Drainage paper. 26. Rome, Italy.

Vermeirn, L. and G. A. Jopling (1984). Localized irrigation. irrigation and drainage paper No. 36, Rome, FAO, Italy.

Wieninger, L. and N. Kubadinow (1971). Beziehungen zwischen $\mathrm{Ru}$ "benanalysen und technologischer Bevertung von Zuckerru" ben. Assem. Commun. Int. Technol. Sucr. 14: 523-538.

Zindahl L. R. (1979). Weed/crop competition. A reveal, Fort Collins, Colorado, USA. Pp 195.

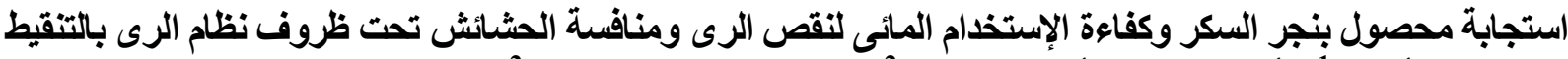

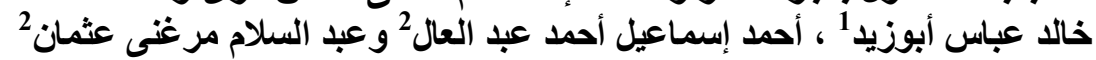

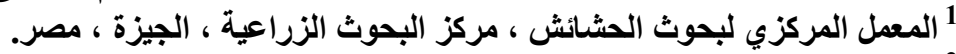

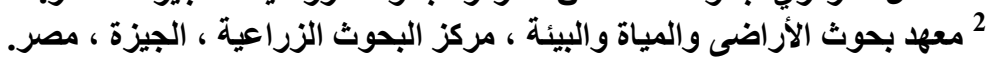

أقيمت تجربتان حقليتان تحت نظام الرى بالتتقيط لمحصول بنجر السكر بمنطقة البستان - مزر عة على مبارك البحثية - جنوب التحرير - محافظة البحيرة وذلك خلال

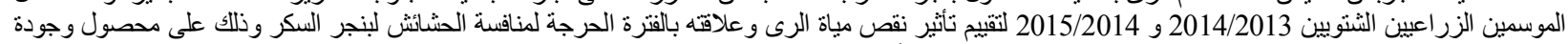

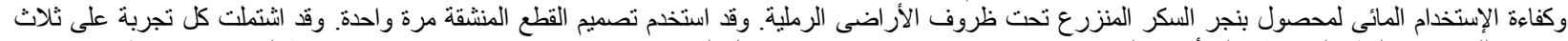

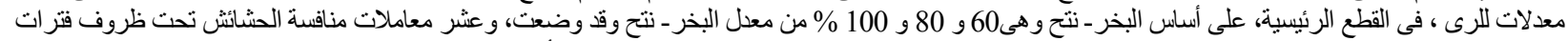

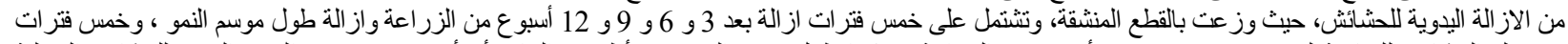

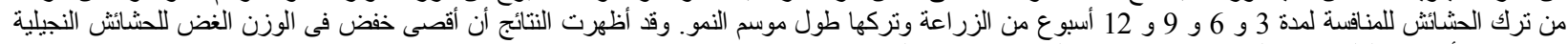

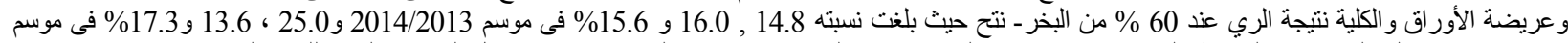

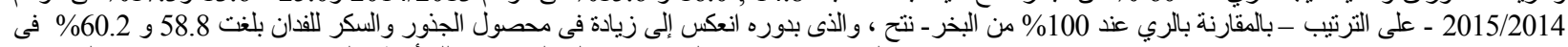

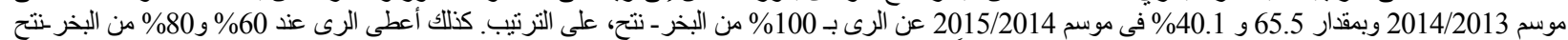

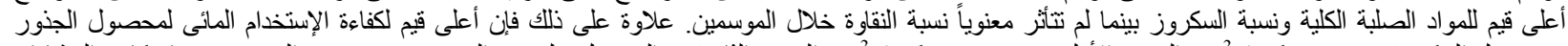

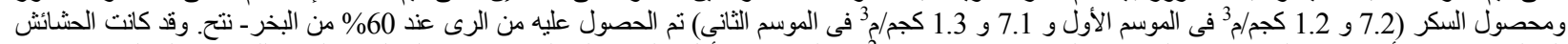

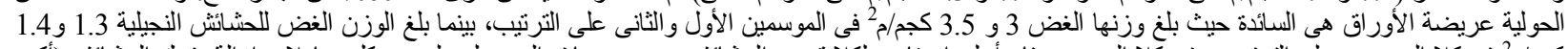

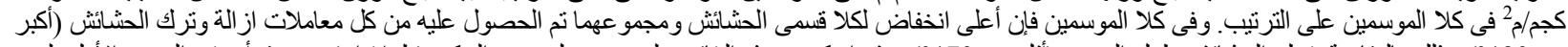

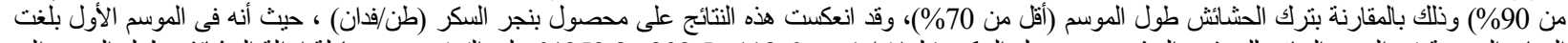

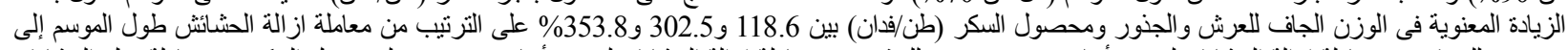

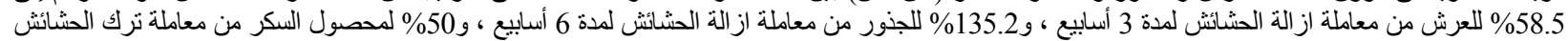

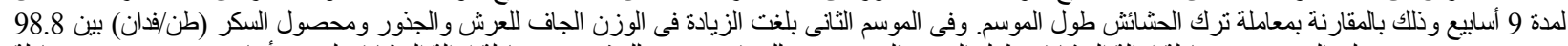

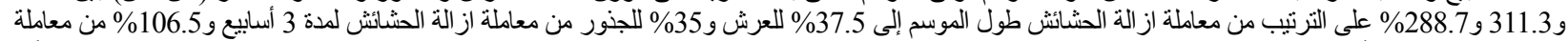

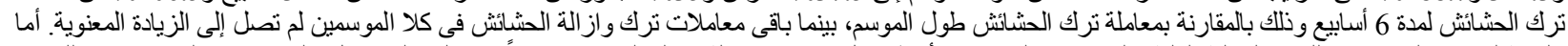

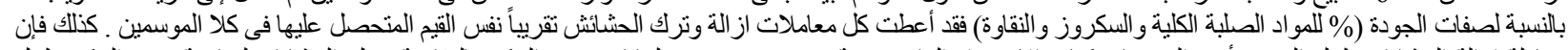

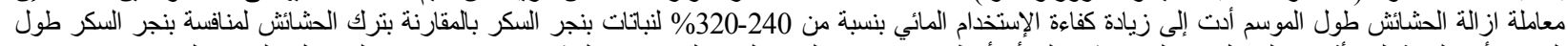

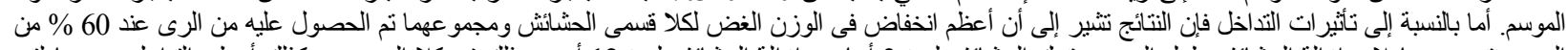

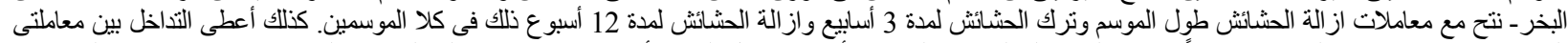

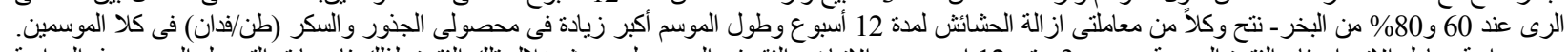

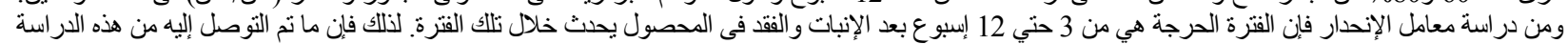

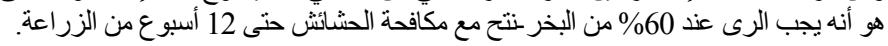

